\title{
Experimentally Investigation of Some Facilities Provided by Hybrid UPSs
}

\author{
İbrahim Güneş ${ }^{1}$, Osman $\mathrm{Okay}^{2}$, Emre Akarslan ${ }^{3 *}$ \\ ${ }^{1}$ ENEL Energy Electronics Company, 43300, Kutahya, Turkey, (ORCID: 0000-0002-6336-5432), igunes@enel.com.tr \\ ${ }^{2}$ ENEL Energy Electronics Company, 43300, Kutahya, Turkey, (ORCID: 0000-0003-2416-8724), ookay@enel.com.tr \\ $3^{*}$ Afyon Kocatepe University, Solar and Wind Energy application and Research Center, Afyonkarahisar, Turkey, (ORCID: 0000-0002-5918-7266), \\ e.akarslan@gmail.com
}

(1st International Conference on Applied Engineering and Natural Sciences ICAENS 2021, November 1-3, 2021)

(DOI: 10.31590/ejosat.1010789)

ATIF/REFERENCE: Güneş, İ., Okay, O. \& Akarslan, E. (2021). Experimentally Investigation of Some Facilities Provided by Hybrid UPSs. European Journal of Science and Technology, (28), 722-726.

\begin{abstract}
Uninterruptible power supplies (UPS), which are used to provide uninterrupted and high-quality energy to the consumer, have also changed in parallel with the developments in the energy sector. In the process, the efficiency of conventional UPSs has increased by developments in power electronics elements, and the dimensions and weights have been reduced with the transformerless UPSs. Recently, UPS systems, which are not indifferent to the developments in renewable energy systems, have achieved a hybrid structure using the energy obtained from these systems. In this study, various advantages of these UPSs are examined experimentally over a sample hybrid UPS via input/output current/voltage waveform. In this context, several features of hybrid UPSs such as feeding the load only through the PV system, supplying the load from the grid and PV system, adapting to on-grid/off-grid operation were examined. The results show that hybrid UPSs are promising in providing uninterrupted, high quality, and efficient energy.
\end{abstract}

\section{Hibrit UPS'lerin Sağladığı Bazı İmkanların Deneysel Olarak İncelenmesi}

Öz

Tüketiciye kesintisiz ve kaliteli enerji sağlamak amacıyla kullanılan Kesintisiz Güç Kaynakları (KGK) da enerji sektöründeki gelişmelere paralel olarak değişimlere uğramıştır. Bu süreçte güç elektroniği elemanlarındaki gelişmelerle konvansiyonel KGK'ların verimliliği artmış, trafosuz KGK'lar ile boyutları ve ağırlıkları azaltılmıştır. Son zamanlarda yenilenebilir enerji sistemlerindeki gelişmelere kayıtsız kalmayan KGK sistemleri, bu sistemlerden elde edilen enerjiyi kullanarak hibrit bir yapıya kavuşmuştur. Bu çalışmada, hibrit KGK'ların çeşitli avantajları, referans bir hibrit KGK üzerinden, giriş/çıkış akımı/gerilim dalga formu aracılığılyla deneysel olarak incelenmiştir. Bu kapsamda hibrit KGK'ların yükün sadece PV sistem üzerinden beslenmesi, yükün şebekeden ve PV sistemden beraber beslenmesi, şebekeye bağlı/şebekeden bağımsız çalışmaya uyum sağlaması gibi çeşitli özellikleri incelenmiştir. Sonuçlar, hibrit KGK'ların kesintisiz, yüksek kaliteli ve verimli enerji sağlama konusunda umut verici olduğunu göstermektedir. 


\section{Introduction}

With the developing technology, electrical devices have become an indispensable part of daily life. For this reason, expectations regarding the continuity and quality of the energy supplied have increased considerably in the last decades. A solution for end-users to achieve uninterrupted and high-quality energy may be to use an uninterruptible power supply (UPS). In facilities such as hospitals, data centers, communication systems, etc., where power cuts can cause significant problems, UPS systems are used to supply critical loads with continuous and high-quality energy (Güneş et al., 2009). In general, the output of the UPS system should be sinusoidally regulated with low total harmonic distortion (THD), independent of changes in input voltage and sudden changes in the load connected to the system (Guerrero et al., 2007). It should also have high power density, low transient response time, high reliability, high efficiency, low electromagnetic interference (EMI) and acoustic noise, electrical insulation, low maintenance, low cost and weight, and small size (Zhan et al., 2008). In general, the UPS system can be classified as Rotary UPS system and Static UPS system. Rotary UPS uses motors and generators to process, store and transmit power in case of mains failure, whereas Static UPS system uses power electronic converters and inverters for the same function (Aamir et al., 2016). The static UPS systems can be classified as Offline UPS, Line-interactive UPS, and Online UPS systems based on topological configuration (Niroomand \& Karshenas, 2010). The offline UPS (Fig. 1.a) basically consists of a battery charger, a static switch, and an inverter. The advantages of the offline UPS can be expressed in its low cost, simple design, and relatively small size, while its problems with real isolation, voltage regulation, and its relatively low performance in the case of nonlinear load are among its major disadvantages. Lineinteractive UPS (Fig. 1.b) has a bidirectional converter/inverter different from the offline UPS, and it has some advantages such as low cost, small size, and high efficiency. However, they are limited to not providing any voltage regulation in normal mode operation (Aamir et al., 2016). In the Online UPS (Fig. 1.c), the load continues to be fed without interruption in a power failure. It provides clean power to the load regardless of the problems in the grid, isolates the load from the mainline, and has a short switching time (Khan et al., 2019), although it has disadvantages such as low efficiency, low power factor, and high total harmonic distortion (Aamir et al., 2016).

A newer UPS technology is transformerless UPS technology, which does not have output stage isolation transformers or input stage phase shift transformers. Transformerless UPS systems have relatively high efficiency, small weight, and volume, but one disadvantage is that they are susceptible to interference from devices connected to the same grid (Aamir \& Mekhilef, 2017). In the input stage, instead of thyristors in traditional phase-controlled rectifiers, Insulated Gate Bipolar Transistor (IGBT) switches can be used in forced commutation PWM amplifier rectifiers (Kaura $\&$ Blasko, 1997). The IGBTs used in the PWM rectifier can boost the intermediate DC bus voltage to a much higher level than the phase-controlled rectifier (approximately $800 \mathrm{~V}$ ) according to the transformer-based UPS case, allowing the inverter to directly generate an $\mathrm{AC}$ output voltage compatible with the rated input voltage (Güneş et al., 2009). As the transformer is removed, transformer-induced efficiency reduction, size/weight increase, thermal reliability degradation, etc., is eliminated. Transformerless UPS systems can provide better total harmonic distortion (THD) and input power factor according to classical transformer UPS systems. In this type of uninterruptible power supply, the battery pack is higher as a higher DC link voltage is needed, and therefore the battery cost increases (Daud et al., 2013). It is also more sensitive to transients and spikes caused by devices connected to the main grid (Koffler, 2003). Recently, hybrid UPSs have become an interesting topic for researchers as they offer the opportunity to benefit from different energy sources. In this paper, some outstanding features of hybrid UPSs are examined. Some features of hybrid UPSs are provided in the following section, then the experimental results obtained by using a hybrid UPS and conclusions are presented.

\section{Hybrid UPS Systems}

Various reasons such as increasing energy need, decreasing fossil resources, environmental sensitivities, transition to smart grids have made renewable energy sources much more popular. The UPS industry did not remain indifferent to this attractive resource. Recently, hybrid UPSs that can use different energy sources apart from battery and main grid have developed. Hybrid UPS is a special type of uninterruptible power supply that can produce electricity uninterruptedly through solar energy (or such a source), battery, grid, or generator in a controlled manner. Since energy can be obtained from different sources, more efficient use and energy security are ensured.
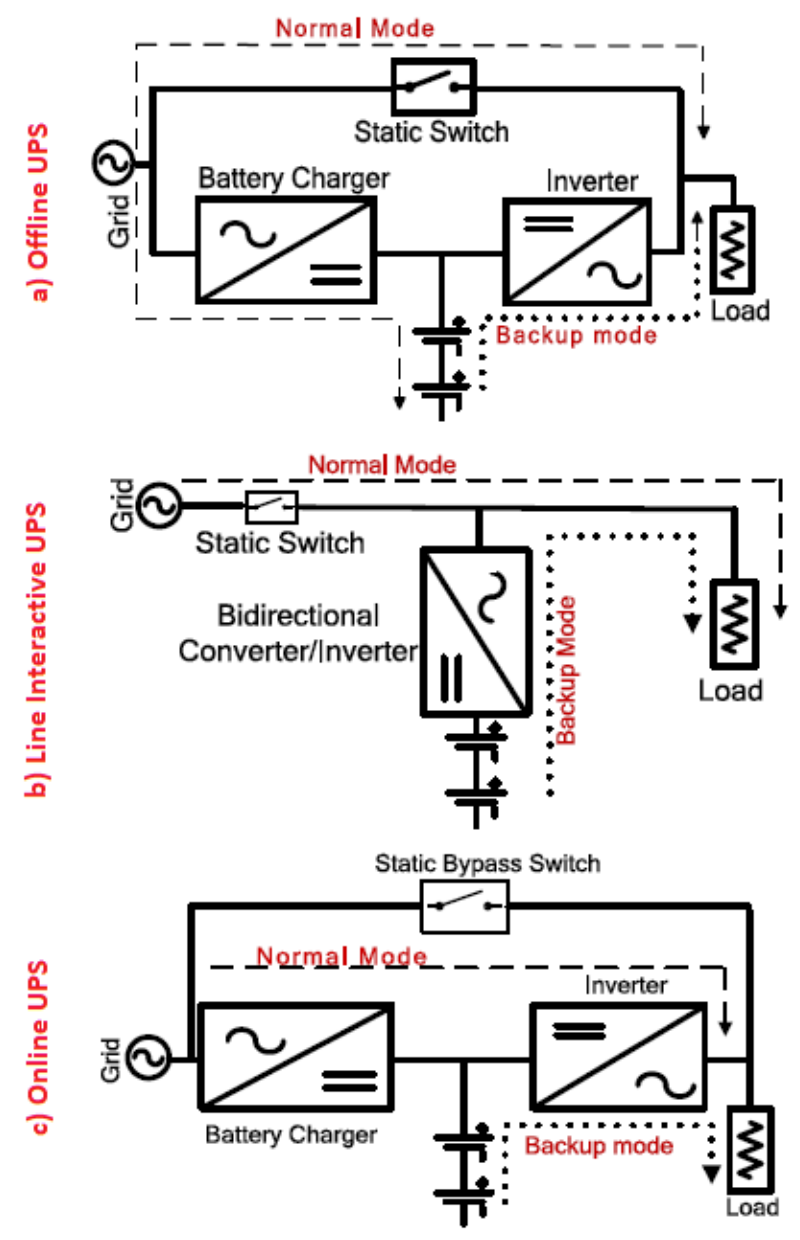

Fig. 1 Block diagram of the Offline (a), Line Interactive (b) and Online UPS systems (Aamir et al., 2016).

In hybrid UPSs, a renewable energy source or a source such as a generator can be used, as well as a storage source such as a fuel cell (Zhang et al., 2013) or supercapacitor (Lahyani et al., 
2013). Since different energy storage devices allow powersharing and due to these storage devices' dynamic behavior and longevity, an improvement in system performance is expected (Aamir et al., 2016). Integrating renewable energy such as wind and solar energy into UPS systems is another way to build a hybrid UPS. Such systems provide more reliable and quality power to the connected load (Bortolini et al., 2014). In the presented study, solar energy integrated hybrid UPS is considered. While classical UPS consists of components such as rectifier, converter, inverter, and filters, hybrid UPS must have circuits that will integrate the energy from this source into the system since photovoltaic panels will also provide energy as a source. The energy produced by a photovoltaic panel is directly related to the solar radiation value falling on it, and the solar radiation value can vary greatly depending on time and atmospheric conditions. For this reason, circuits that will maximize the energy obtained from the PV and keep the energy in a suitable form for the system are needed under this variability. One of the structures used in this context is the maximum power point trackers (MPPT). Moreover, although different energy sources are used at the input, appropriate control strategies must be developed to obtain a UPS output in certain electrical standards. However, integrating an additional source such as PV into the UPS system increases its reliability (Vieira \& Pires, 2016). A sample schema for a hybrid UPS system is presented in Fig. 2. As seen in this schema, the connection of DC sources (PV and Battery) to a DC bus can be a solution for constructing such a system. In connection with PV output and batteries to the DC bus, DC/DC convertors and MPPTs can regulate the charge/discharge of the batteries and the efficiency of the PV system (Vieira \& Pires, 2016). Although it is seen that hybrid UPS systems in different topologies have been created in the literature, and each structure has various advantages and disadvantages, it is seen that these structures provide more effective energy use than traditional UPSs.

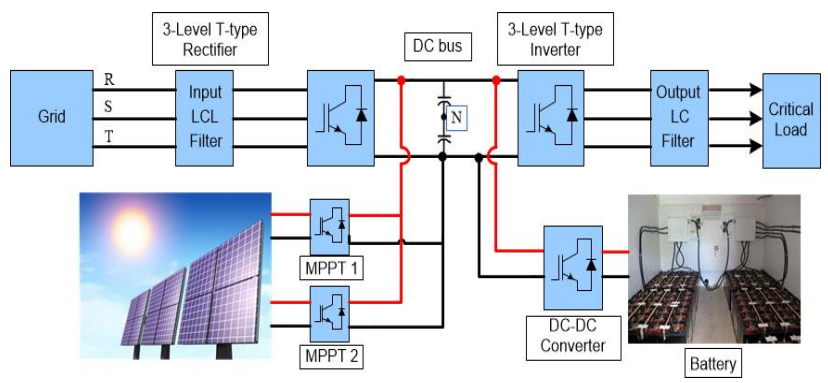

Fig. 2 The principal schema of a hybrid UPS system

\section{Results and Discussion}

In this study, some advantages of hybrid UPSs are examined with reference to a $10 \mathrm{kVA}$ Enel trademark UPS. Some electrical characteristics of the UPS used are presented in Table 1. This UPS allows the PV system to operate in both on-grid and off-grid modes. As seen from the table, there are two MPPTs in the UPS, and the PV output current is measured from one of the MPPT. It means that the measured PV output current is twice the value seen in the figures presented. In addition, network measurements were carried out on a single-phase, and evaluations were made by taking this situation into account while interpreting the figures. Furthermore, the load demand has been increased or decreased in some experiments to show some properties.

One of the advantages of such a hybrid UPS is that it can work as a solar inverter. All energy produced by the PV system can be fed into the grid, just as in a grid-tied solar system, as seen e-ISSN: 2148-2683 in Fig. 3. In this figure, the green line (C4) illustrates the PV panel output current while the brown line $(\mathrm{C} 1)$, the red line $(\mathrm{C} 2)$ and the blue line (C3) represent the grid voltage (input voltage of the UPS), output current of the UPS and output voltage of the UPS, respectively. As can be seen, the blue line is in the opposite direction to the brown line and indicates that energy is being transferred to the grid. All energy is transferred to the grid in this mode, and no current is consumed by the load. It is clear from the red line that no current is drawn by the load.

Table 1. Some electrical specifications of the selected UPS

\begin{tabular}{|c|c|c|}
\hline \multirow{4}{*}{ AC Input } & Voltage & $\begin{array}{c}\text { 380/400/415 Vac } 3 \\
\text { phase }+\mathrm{N}\end{array}$ \\
\hline & Frequency & $50 / 60 \mathrm{~Hz}$ \\
\hline & Power Factor & $\geq 0.99$ \\
\hline & $T H D i$ & $<\% 5$ \\
\hline \multirow{5}{*}{ DC Input } & $\begin{array}{l}\text { Nominal Input } \\
\text { Voltage }\end{array}$ & $650 \mathrm{~V}$ \\
\hline & $\begin{array}{c}\text { Max DC Input } \\
\text { Voltage }\end{array}$ & $800 \mathrm{~V}$ \\
\hline & $\begin{array}{c}\text { Operating Voltage } \\
\text { Range }\end{array}$ & $200-800 \mathrm{~V}$ \\
\hline & MPPT Voltage Range & $400-650 \mathrm{~V}$ \\
\hline & Number of MPPT & 2 \\
\hline \multirow{5}{*}{$\begin{array}{c}\text { AC } \\
\text { Output }\end{array}$} & Voltage & $\begin{array}{c}\text { 380/400/415 Vac } 3 \\
\text { phase }+\mathrm{N}\end{array}$ \\
\hline & Max Output Power & $9 \mathrm{~kW}$ \\
\hline & Power Factor & 0.9 \\
\hline & Frequency & $50-60 \mathrm{~Hz}$ \\
\hline & $T H D v$ & $\begin{array}{c}<\% 2(\text { linear load }) \\
<\% 5 \text { (nonlinear load) }\end{array}$ \\
\hline \multirow{3}{*}{ Battery } & Nominal Voltage & $240 \mathrm{~V}$ \\
\hline & Charge Voltage & $270 \mathrm{~V}$ \\
\hline & Number of Batteries & 20 \\
\hline \multirow[t]{2}{*}{ Efficiency } & AC/AC Mode & $\% 96$ \\
\hline & $D C / A C$ Mode & $\% 97$ \\
\hline
\end{tabular}

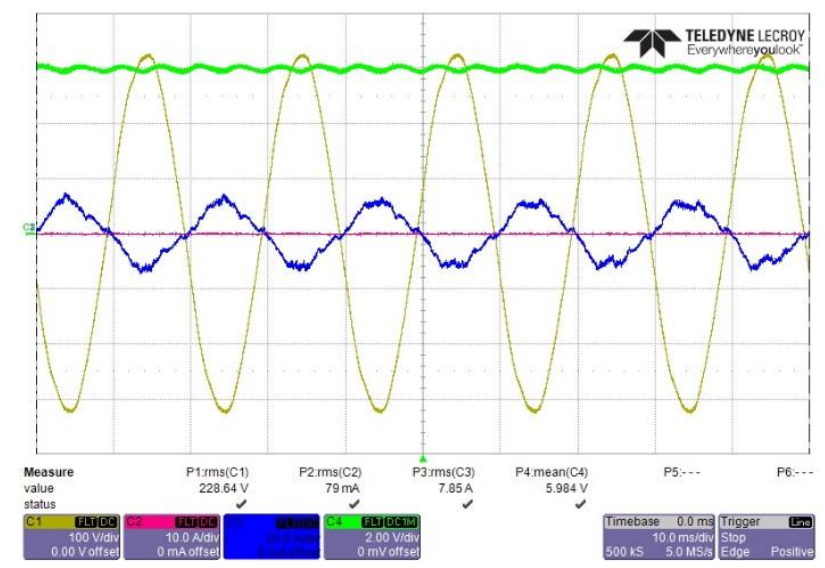

Fig. 3 Transferring all the energy produced from PV to the grid in on-grid mode

In another mode, all produced energy from the PV is transferred to the load. This mode is useful in case of the produced energy from PV is enough for load demand. Fig. 4 illustrates the obtained measurement on this mode. As can be seen from the figure, there is no current flow to the grid side (blue line) while the current is drawn from the load side (red line). However, the 
energy produced from PV does not always meet the demand of the load. In this case, when operating in on-grid operation mode, the energy produced from the PV and the energy drawn from the grid (the amount that the PV cannot meet the demand) together meet the demand of the load. It can be seen from Fig.5 that this can be done with a hybrid UPS.

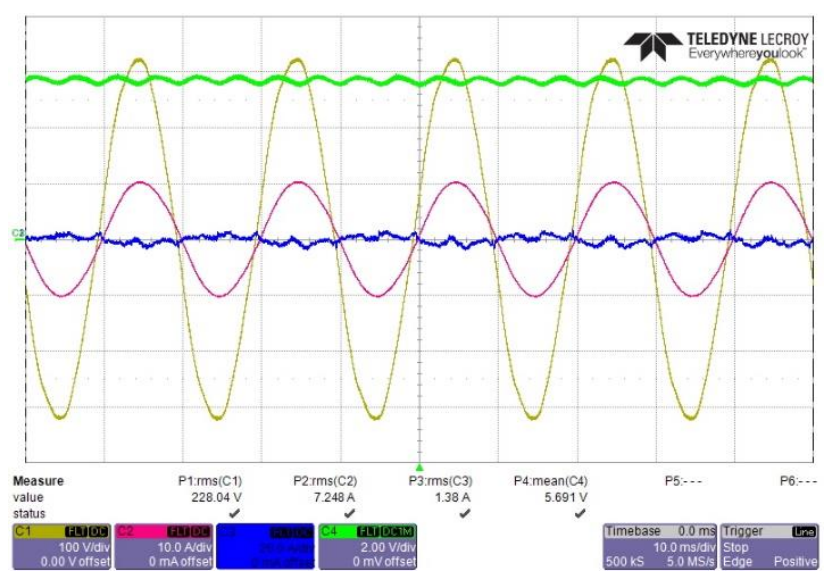

Fig.4. Transferring all the energy produced from PV to the load in on-grid mode

In order to demonstrate this feature, the load demand has been increased to be above the energy supplied from the panel. In Fig. 5 , please note that current is drawn from both the grid (blue line) and the PV panel (green line) to meet the load demand (red line). Please note that the PV current is measured from one MPPT, while the consumed current from the grid is measured only from the $\mathrm{R}$ phase, and the scale of each measure is different from the other.

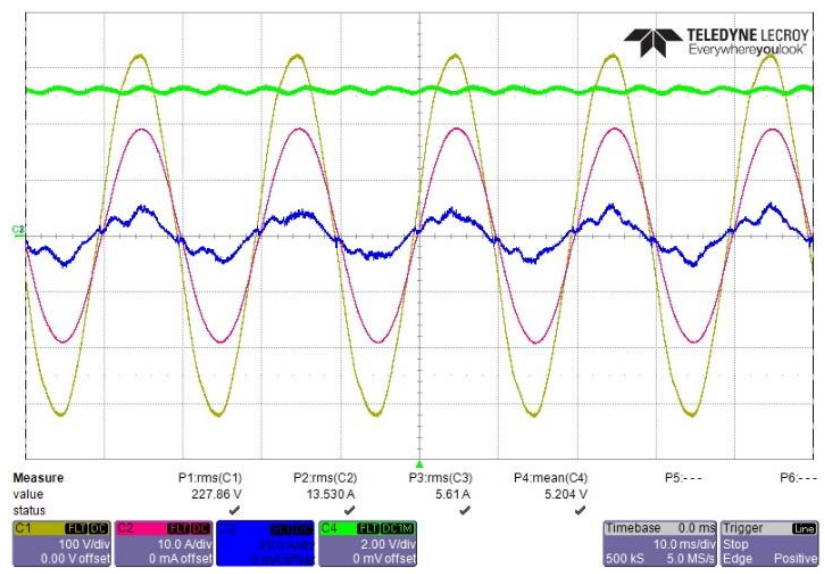

Fig. 5. Meeting the demand of the load from the PV and the grid together

When the UPS operates in on-grid mode, it may need to switch to off-grid mode with a mains failure. This is illustrated in Fig. 6, and in this figure, the blue line represents the UPS output voltage different from the previous figures. Although a temporary fluctuation is observed in the current drawn from the panel (nearly 15 cycles) with the grid interruption, there is almost no fluctuation in the voltage on the load (UPS output). This situation is not very different from the situation where the need is met by the UPS battery when the mains is cut off. However, in the hybrid UPS, the support of the PV panel and the battery provide a more stable signal at the output.

In on-grid mode, energy can be drawn from the grid or fed to the grid. However, a bidirectional meter is needed in case the energy is to be fed into the grid. In this way, offsetting can be done e-ISSN: 2148-2683 by measuring the energy fed to and drawn from the grid. If there is no two-way counter and one-way counter, then the energy fed to the grid is also perceived as consumption. For this reason, in the case of a one-way meter, excess energy should never be pumped into the grid. The selected UPS for experiments has an option called as not feeding energy to the grid. Fig.7 and Fig.8 reveal this feature from different perspectives.

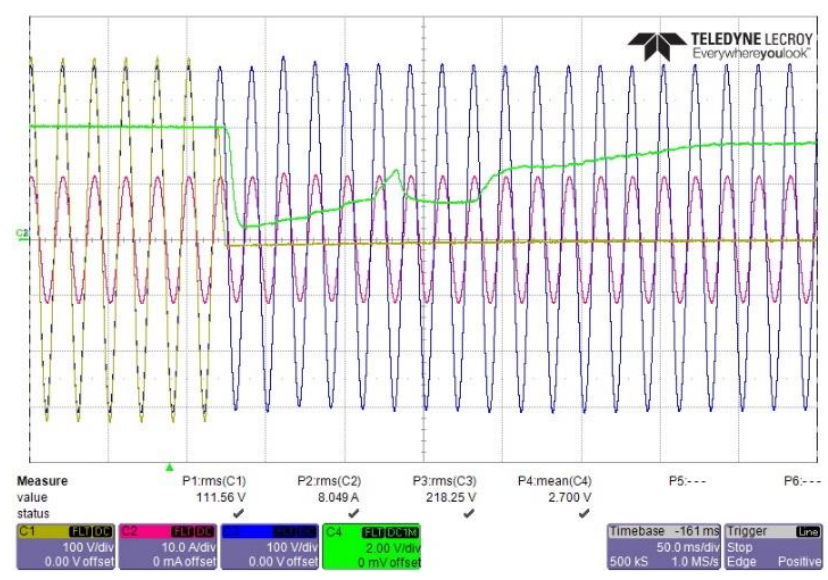

Fig. 6. Switching from on-grid mode to off-grid mode

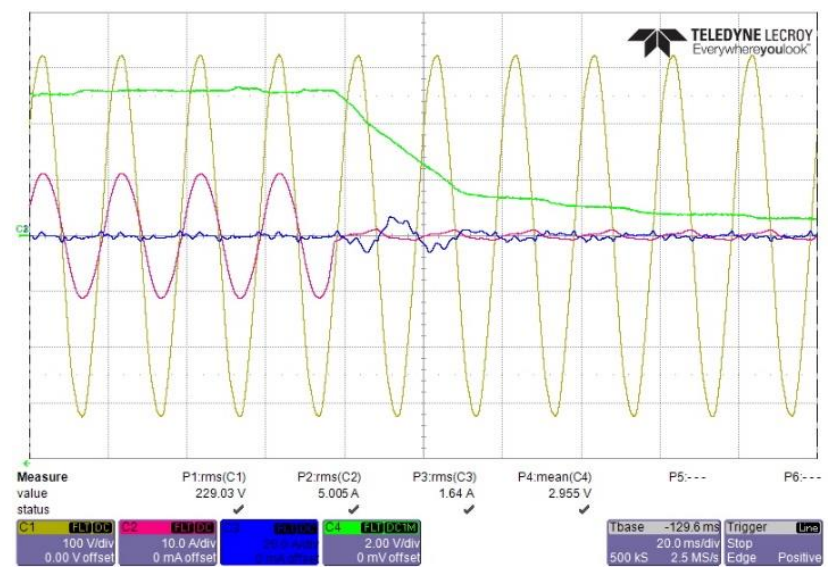

Fig. 7. No power to the grid mode (sudden decrease in load demand)

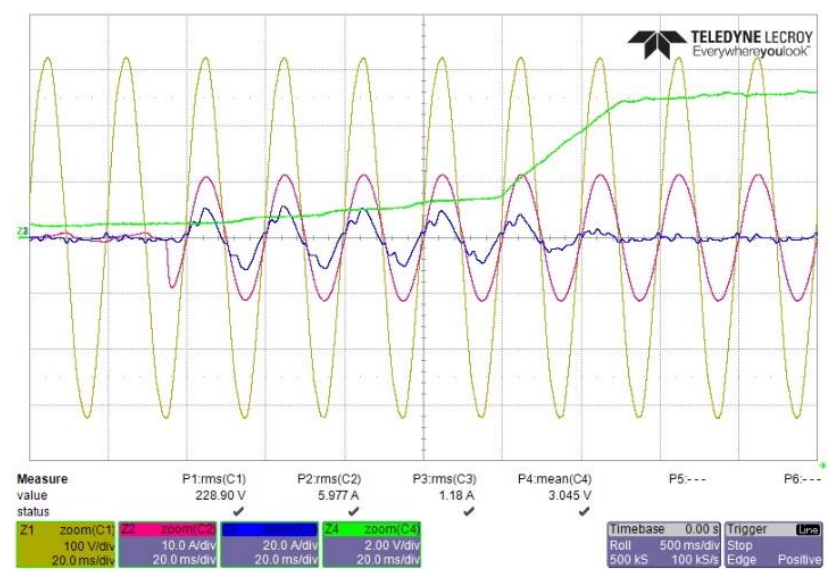

Fig. 8. No power to the grid mode (sudden increase in load demand)

In Fig. 7, while the output load is provided from the PV without drawing current from the grid, if the demand of the load (red line) decreases, the energy drawn from the PV (green line) is reduced, and the back current (blue line) is prevented from being 
fed to the grid. In Fig. 8, it is seen that the energy produced by the PV (green line) is limited and thus not fed into the grid since the load demand (red line) is very low at the beginning. However, when the load demand suddenly increases, after the required energy is met from the grid (blue line) for a very short time, the current drawn from the PV (green line) is increased and the load is fed from the PV. Similarly, enough energy must be drawn from the PV panels to meet the load demand when operating in off-grid mode. It is clear from Fig. 9 that this can be achieved with the selected hybrid UPS. In this figure, it can be seen that, if the load demand (red line) decreases, the PV current (green line) decreases linearly. The brown line (mains voltage) constant at zero indicates that it operates in off-grid mode. Experiments conducted in this study show that hybrid UPSs have some crucial advantages over conventional UPSs, and only some of them are discussed here. It is seen that hybrid UPSs provide a more efficient and stable working environment by including the solar system in addition to the uninterrupted and clean energy provided by traditional UPSs.

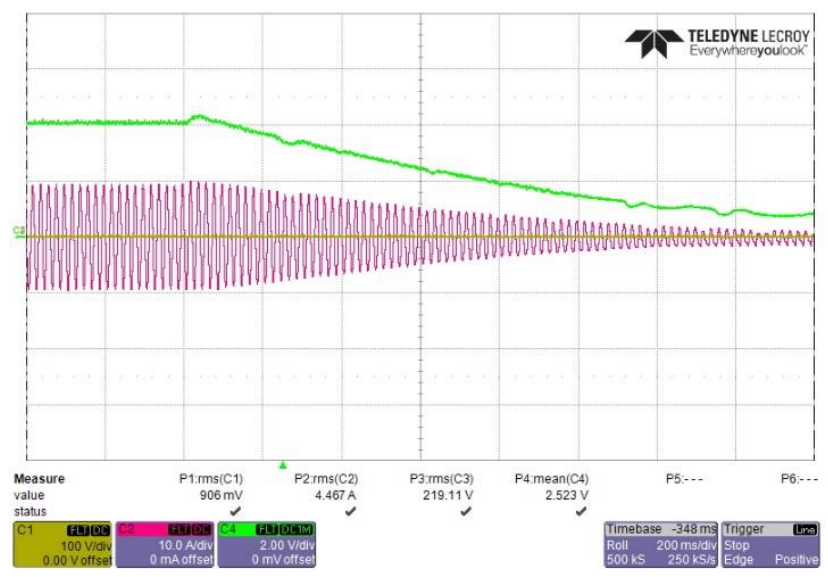

Fig. 9. Reduced load demand in off-grid mode

\section{Conclusions and Recommendations}

In this study, some advantages of the hybrid UPS systems are experimentally investigated. Some possibilities provided by hybrid UPSs are examined by using a sample hybrid UPS with 10 kVA power. In this context, firstly, UPS was used as a solar inverter, and all the energy produced from the PV system in the no-load condition was transferred to the grid. Secondly, by commissioning the load, again in on-grid mode, the load was fed with the energy produced from PV, then the load demand was increased, and the needed energy was met by drawing from the grid and PV. Then, while the UPS was operating in on-grid mode, the grid was suddenly cut off, and the UPS's rapid transition to off-grid mode was observed. Finally, the ability of the selected UPS to limit the PV current when necessary is examined. In case of a sudden increase or decrease of the load in on-grid mode, the adaptation of the PV current to this situation has been investigated. It has been determined that the PV current can be reduced linearly with the decrease in the load demand in the offgrid mode. As a result of the study, it has been determined that hybrid ups provide significant advantages in providing uninterrupted and high-quality energy and efficiently using energy resources.

\section{References}

Aamir, M., Ahmed Kalwar, K., \& Mekhilef, S. (2016). Review: Uninterruptible Power Supply (UPS) system. Renewable and Sustainable Energy Reviews, 58, 1395-1410. https://doi.org/10.1016/J.RSER.2015.12.335

Aamir, M., \& Mekhilef, S. (2017). An Online Transformerless Uninterruptible Power Supply (UPS) System with a Smaller Battery Bank for Low-Power Applications. IEEE Transactions on Power Electronics, 32(1), 233-247. https://doi.org/10.1109/TPEL.2016.2537834

Bortolini, M., Gamberi, M., \& Graziani, A. (2014). Technical and economic design of photovoltaic and battery energy storage system. Energy Conversion and Management, 86, 81-92. https://doi.org/10.1016/J.ENCONMAN.2014.04.089

Daud, M. Z., Mohamed, A., \& Hannan, M. A. (2013). An improved control method of battery energy storage system for hourly dispatch of photovoltaic power sources. Energy Conversion and Management, 73, 256-270. https://doi.org/10.1016/J.ENCONMAN.2013.04.013

Guerrero, J. M., de Vicuña, L. G., \& Uceda, J. (2007). Uninterruptible power supply systems provide protection. IEEE Industrial Electronics Magazine, 1(1), 28-38. https://doi.org/10.1109/MIE.2007.357184

Güneş, İ., Üstüntepe, B., \& Hava, A. M. (2009). Modern transformerless uninterruptable power supply (UPS) systems. 2009 International Conference on Electrical and Electronics Engineering - ELECO 2009, I-316-I-320. https://doi.org/10.1109/ELECO.2009.5355256

Kaura, V., \& Blasko, V. (1997). Operation of a voltage source converter at increased utility voltage. IEEE Transactions on Power Electronics, 12(1), 132-137. https://doi.org/10.1109/63.554178

Khan, H. S., Aamir, M., Ali, M., Waqar, A., Ali, S. U., \& Imtiaz, J. (2019). Finite Control Set Model Predictive Control for Parallel Connected Online UPS System under Unbalanced and Nonlinear Loads. Energies 2019, Vol. 12, Page 581, 12(4), 581. https://doi.org/10.3390/EN12040581

Koffler, R. (2003). Transformer or transformerless ups? IEE Power Engineer, 17(3), 34-36. https://doi.org/10.1049/PE:20030310

Lahyani, A., Venet, P., Guermazi, A., \& Troudi, A. (2013). Battery/Supercapacitors Combination in Uninterruptible Power Supply (UPS). IEEE Transactions on Power Electronics, 28(4),

https://doi.org/10.1109/TPEL.2012.2210736

Niroomand, M., \& Karshenas, H. R. (2010). Review and comparison of control methods for uninterruptible power supplies. PEDSTC 2010 - 1st Power Electronics and Drive Systems and Technologies Conference, 18-23. https://doi.org/10.1109/PEDSTC.2010.5471864

Vieira, C., \& Pires, V. F. (2016). Hybrid PV-UPS system with multilevel structure of power converters and reliability improvment. 2016 IEEE International Conference on Renewable Energy Research and Applications, ICRERA 2016 , 873-878. https://doi.org/10.1109/ICRERA.2016.7884461

Zhan, Y., Guo, Y., Zhu, J., \& Wang, H. (2008). Intelligent uninterruptible power supply system with back-up fuel cell/battery hybrid power source. Journal of Power Sources, 179(2),

745-753. https://doi.org/10.1016/J.JPOWSOUR.2007.12.113

Zhang, W., Xu, D., Li, X., Xie, R., Li, H., Dong, D., Sun, C., \& Chen, M. (2013). Seamless transfer control strategy for fuel cell uninterruptible power supply system. IEEE Transactions on Power Electronics, 28(2), 717-729. https://doi.org/10.1109/TPEL.2012.2204777. 